\title{
The Role of Government and Religion in Combating Violence in Nigeria: The Niger Delta Experience
}

\author{
Osunyikanmi, Pius Olakunle (Ph.D.) \\ $\mathrm{COE} /$ Directorate of Nigerian Technical Aid Corps \\ Email: osunyikanmi2003@yahoo.com \\ Phone: +2348034711143 \\ Sapele, Frank Funkeye \\ Department of Political Science, \\ University of Africa \\ Sagbama, Bayelsa State, Nigeria \\ Email: sapelefrank@gmail.com \\ Phone: $+256758068189,+2348039319607$
}

\begin{abstract}
This paper focuses on the role of government and religion in combating violence in Nigeria: The Niger Delta Experience. Nigeria has been entangled with several ethno-religious conflict which affects good governance and the practice of religion since the return of democracy in 1999, but the government and religious organizations are charged with the formulation and implementation of public policy through the mobilization of national resources and their allocation for the attainment of societal goals. Government and religious organizations have been trying to meet up the increasingly heavy demands and challenges of tackling violence among the citizens within the nation. The study argues that violence is common and unavoidable in all spheres of human existence, violence occur because society is composed of people with differing interests and values. It was revealed that violence activities among different groups is common in Nigeria and it is increasing through widespread violence, kidnapping for ransom, classes between groups, destroying properties, killing of innocent people, destruction of people's farmland, oil blocks, mass protest and civil disobedience. The study employed qualitative approach and utilized content analysis. Thus, the study employed secondary sources of data. The paper recommended that the government should identify countries that experience similar inter-communal conflict and initiate policies against violence act, the government and religious groups should press for accountability for perpetrators and instigators of violence to combat impunity.
\end{abstract}

Key words: - Conflict, Ethno-religious, Government, Religion, Violence.

Journal Reference Format:

Osunyikanmi, P.O \& Sapele, F.F. (2019): The Role of Government and Religion in Combating Violence in Nigeria: The Niger

Delta Experience. Humanities, Management, Arts, Education \& the Social Sciences Journal. Vol. 7 . No.1, Pp 31-36.

Article DOI: dx.doi.org/10.22624/AIMS/HUMANITIES/V7N1P4. Available online at www.humanitiesjournal.org

\section{INTRODUCTION}

Violence activities have affected service delivery in Africa and especially in Nigeria. Over the years, violence has threatened Nigeria's peace, stability and unity. As the current administration is fighting war against terror in the North-East Nigeria, also militant groups in the Niger Delta (South-South) have brought different violence actions, because violence occur when parties in a state independence perceives diverse views or 
believe that their aspirations or goals cannot be achieved simultaneously. Violence in Nigeria has taken various forms as; in the Northern Nigeria it involves religious violence, extremist attacks, South-East it involves Cultism, Robbering, Kidnapping, while in the South-West it involves political violence, thuggering, Robbering, on the other hand, in the South-South Nigeria violence activities involves kidnapping, cultism, robbering, destruction of people properties and Oil blocks, Intimidation, Tribal class, abuse among others. Since the returned of democracy in 1999, the Muslims in the Northern, the Western which comprises Muslims and Christians, and the Southern Nigeria had experienced in different act that posses dangers to the government and religious groups in Nigeria.

Violence activities in Nigeria have showed much causalities. It has affected and lead to millions of death, discouragement of foreign investment, influxes of refugees and displaced people. But Government and religion has help to meet up the heavy demands and challenges of tackling violence activities among the citizens within the nation. Government and religion has help to fosters in effective and efficient tool in combating violence activities in Nigeria and in relation to the Niger Delta states.

Jona and Okou (2014) religion through the government has helps in the following roles in combating violence in Nigeria. It is fundamentally rooted in faith, it emphasizes spirit of service and core, its rituals are essentially expressive and process oriented, its emphasis are on asceticism, stress, discipline, self-denial, repetition and character molding. In fact, the biblical scripture (Mark 12:31, Leviticus 19:18) added "Love your neighbour as yourself". Consequently, a society like Nigeria that needs to survive on even development government and religion could serve and has indeed served as an instrument of social harmony in many civilizations.

\section{CONCEPTUAL CLARIFICATION}

\subsection{The Concept of Violence}

Obasi, (1984:440) define violence as behaviour intended to cause bodily pain or injury to another. World Health Organization (2016) violence is defined as the intentional use of physical force of power, threatened or actual, against a group or community, which either results in or has a high likelihood of resulting in injury, death, psychological harm, maldevelopment; or deprivation, Sedman (1991:370) violence is not an inherent aspect of conflict but rather a potential form that conflict my take. Duvall and Ackerman (2008) in Govier (2008) violence refer to the sort of physical violence involving in war, terrorism, and revolution; the tools of violence include guns, tanks, bombs, and other instruments of physical force. Violence methods include intentional killing, beating, assaulting, torturing, wounding, or damaging by the use of physical force.

\subsection{Government}

Government means a body of people vested with power to make and enforces law in a given country. Government is charge with the formulation and implementation of public policies through the mobilization of national resources and their allocation for the attainment of societal goals. Government is a group of people who exercise authority over a group of people in a state, society or country. Government performs several roles in the society which includes; Policy formulation, implementation, provision of social services to the people, provision of citizenship education and training, employment generation, improving welfare of the citizenship and among others. Government provides public policies to the citizens which help for effective and efficient service delivery in Tambou (2016). 


\subsection{Religion}

According to Vincent (2014 - 1:2) it is an organized system of beliefs, ceremonies, practices and worship that are centered on the duty or supreme being It is important to note that many people especially in Africa belong to more than one religion. In other words, they are syncretistic.

Coakely (2007) in Jona and Okou (2013:61) sees religion as a socially shared set of beliefs and rituals that people use to transcend the material world and give meaning to important aspect of their lives. Religious beliefs and ritual are unique because people connect them with a sacred and supernatural realm and accept this connection on faith, which is the foundation for all religions and religious beliefs. Religion in relation to human being is regarded as holy, sacred, spiritual and divine way which further has power or powers that control human destiny. Hence, it is a person's relation to God or god's or spirits which could also mean faith, believe and/ or mode of worship. Worship here, is probably the most basic element of religion, but moral conduct, right belief and participation in religious institutions are the general constitute elements of religious life as practiced by believers and as commanded by religious sages and scriptures. Thus, religion is the source of illumination and the cause of development in all human advancement which has been the basis of all civilization and process in the history of mankind. Religion is the source of meaning and hope for the vast majority of the inhabitants of the planet and it has limitless power to further inspire sacrifice, commitment and change among its followers.

\subsection{The Role of Government and Religion in Combating Violence in Nigeria-Niger Delta States}

Government and religion has played diverse roles in curbing violence in Nigeria and especially in the Niger Delta region. Importantly, the Nigerian government through the help of the state governments have map of strategies in combating violence in the Niger Delta region which includes;

- Provision of public goods and services: Government performs the role of providing public goods and services that will meet the demands of the citizens at any point in time.

- Protection of civil Liberties: Government through this means help to establish an efficient civil liberties process in providing service delivering within the public.

- Promotion of economic growth and development: Government seeks to facilitate and foster the growth and development of the nation's overall economy.

- Provision of training program and employment generations: Government also help to provide massive training programs for the teeming youth and also provide employment opportunities especially for the unemployed graduates that will help to curb violence act.

- Protection of life and properties: Government at any point in time protects life and properties. This process is achieved through the use of the military and police force to curb violence in act in the state. While on the other hand, religion which plays the following roles in curbing violence in the Niger Delta region.

- Prayer: Prayer has been adjudged as the best powerful tool in resolving violence in Niger Delta region that is, by praying to God, any problem can be solve because God is Omnipotent God answers the prayer at any point in time. 
- Condemning violent acts by religious leaders: Another role plays by religion is condemning act of violence. Because in the old Testament, God sent prophet's to condemn the Israelite Kings who had gone astray and caused conflicts e.g Samuel condemned King Saul (1sam 15:10-35), prophet Nathan condemned King Solomon for having oppressed God's people (1Kings 17:21:20-29). Religion has help greatly in averting different violent acts in the Niger Delta region many religious groups often condemn and stand against all forms of violence act in the region.

- Advocating of peace mediation between warring factions: Through peace mediation, religion play a crucial role in conflict, violence resolution and management. Religious organizations in the world over have involved in resolving violence among warring groups. Christian Association of Nigeria (CAN) has several times represented the Nigerian government in settling dispute between the government and the Niger Delta militant groups.

- Performance of rituals that can cause peace: This also helps in solving violent act among the Niger Delta region. For instance the offering of sacrifices to the spirit is emphasized; it is believed that by making them happy, they can cause peace happen. Because spirit can deliver people's prayers to God for him to make people get what they want.

- Making people to follow religious teaching. Another role played by religion is the process of teaching the public in other to convert and follow up the good life. For instance, teaching can come from people to leave holy life, repenting from sins or evil and turning back to God. All the world religious groups teach that by repenting and stopping evil acts, violence might have been existing in homes/families, organizations, societies and countries are more likely to stop. More so, in embracing Islamic religion prophet Mohammed (Phub) condemned these evils and many people stopped them. Similarly, in the bible, Paul, originally called Saul was a strong persecutor of Christians but when he was going to Damascus to arrest and imprison Christians, his life was changed and henceforth became a true follower of Christ (Acts 9:1-19, 22:6-16, 26:12-18). This means that, when the people decided to stop evil and live in holy lives, this can stop or prevent prevailing violent act in the Niger Delta State. Okou (2014:61) it is undoubtedly true that religion is a major influence in the world today, it is worthy of note that people in all cultures seem to have a set of beliefs that go beyond both itself and the natural world.

2.5 Challenges Government and Religious Leaders faced in combating violent in the Niger Delta Region.

It is an incontrovertible fact to note that in resolving violent act in the Niger Delta Region, there are lots of obstacles who affect it process, and among these are:

- One challenge government and religion face in resolving violence is the issue of religious fundamentalism

- Another challenge is doubting nature of the people. That is, the belief among many politicians that miracles do not occur in the political field, so prayers as it is believed cannot solve political problems.

- Many at times, Religious Leaders needed peace and at the same time armed violence as a way of achieving peace, so a conflict of interest may prevail. This shows with some religions that support violence against the enemy.

- Many soldiers understand strongly the use of "language of the gun", it is what they fear, not the words. This makes them fail to listen to the news of religions leaders and which the government also failed to play a part in condemning the view. 
- Religion intolerance among the people. Another obstacle in combating violence in the Niger Delta Region is the problem of Religion intolerance among the people, because different religions groups fail to tolerate other religions groups in the area. That is the divides of Pentecostal, Anglican, Catholic Churches and the traditional, Islam groups, these greatly affect it role in resolving violence.

- The problem of corruption among government officials and religions leaders. Many government personnel's and religions leaders are alleged to be corrupt, sexually immoral, cheats, liars and irresponsible, these make the people of the Niger Delta region not to take their words seriously and which can lead to more violence act in the area.

- Problem of nepotism, tribalism and favoritism. These are big obstacle in combating violence in the Niger Delta Religion. Because politicians and religions leaders always considered their tribes, well wishers in position and these greatly hinder the fight against violence in the Niger Delta areas. For instance, some leaders in the Niger Delta Region have accuse the current administration of Nigeria in sideling the Niger Delta areas of appointments, that the government has failed to adhere to the principles of Federal Characters where every positions should cut across every parts, this issue has cause hatred which has brought in another militants group called Niger Delta Avengers which at present have been attacking and destroying pipelines in the Niger Delta area every given month.

\section{METHODOLOGY}

The study employed qualitative approach and utilized content analysis. The secondary sources of data was employed to ascertain the effective role plays by government and religion that geared towards curbing violence in the Niger Delta Region.

\section{FINDINGS AND CONCLUSION}

The study observed that violence is very common in the Niger Delta Region and unavoidable in all sphere of human society, because violence is composed of people with differing interests and values. But government and religion has tried in several means in combating different violence activities in the Niger Delta Region. Government and Religion plays compatible roles in standing against violence act in the Niger Delta States of Nigeria and in relation to the Niger Delta region. The government through different states in the Niger Delta region had introduced several skills acquisition programs that will help to reduce or stop violence act in the region.

\section{RECOMMENDATIONS}

Based on these, the study recommended the following ways in combating violence in the Niger Delta States of Nigeria.

i. Government and religions groups should stop the issue of intolerance among their fellow citizens. That if they tolerate each other it will help to promote unity in the fight against violence

ii. Government and religions groups should stand against favoritism, nepotism and tribalism in dealing and sharing of public positions, in doing so, it will help to curb violence act.

iii. Government and religions groups should draw instances of countries that faces similar intercommunal violence and have initiated policies against radicalization and violence 
iv. Government and religion leaders should organize and fund nationwide civic education program that will inculcate the significance of a common nation of citizenships, based on respect of ethnic and religious diversity, national unity and cohesion

v. Government and religions groups should take measures against discrimination in education and employment opportunities between the indigenes.

vi. Government and religions leaders should press for accountability for perpetrators and instigators of violence to combat impunity.

vii. Government and religion as a subject should be made compulsory for students at all levels of the educational system which will help to instill moral conduct, and the Bible and the Holy Qur'an which are the basis of the religions studies in Nigeria should be emphasized on the communal expectations of man to uplift moral and religious values

\section{REFERENCES}

1. Athalif-Deen.(2005) Politics: U.N. Member States Struggle Define Terrorism, Inter Press Service

2. Chapman G. (1984). Christian living today, Book two. London: Cassel Ltd.

3. Hastings A. (1976). African Christianity. New York: Macmillan Publishing Co.

4. Hoffman, B. (1998). Inside Terrorism. Columbia University Press

5. Kealy, P.J. \& Shenk, D. W. (1975). The Early church and Africa. Oxford University Press.

6. Record, J. (December 2003). "Bounding the Global War on Terroism". Strategic Studies Institute (SSI). Retrieved 2009-11-11.

7. Tambou, J.T. (2016). Introduction to Political Science. Unpublished Lecture Notes.

8. Tuma, T. \& Mutilbwa, P. (1978). A Century of Christianity in Uganda, 1877-1977. Nairobi: Uzima Press Ltd.

9. Welch, E. and Benard, S. (1990). The Fulfillment. Nairobi: Oxford University Press.

10. Des Forges, A. (1999). Leave No One to Tell the Story: Genocide in Rwanda. Human Rights Watch. ISBN 1-56432-171-1.Retrieved January 12, 2007.

11. Rene' Lemarchand (20020. "Disconnecting the Threads: Rwnda and the Holocaust Reconsideredd", Idea Jounal, Vol. 7,No. 1, March

12. Vincent,K (2014). Conflict Escalation and Resolutons;The Role of Religion.Kampala, LNA Ltd.

13. Govier, T (2008). Peace Research Vol. 40. No. 2

14. Johan, G (1969). Volence, Peace and Peace Research Journal of Peace Research 6, No. 3

15. Okou,F.T (2014). My Treasure; Marriage and Family Sustanability in Nigeria. Calaber.Ltd 